Available online at www.banglajol.info

Bangladesh J. Sci. Ind. Res. 44(1), 41-50, 2009
BANGLADESH JOURNAL OF SCIENTIFIC AND INDUSTRIAL RESEARCH

E-mail: bjsir07gmail.com

\title{
Chemical and Physical Analyses of Selected Cement Samples in Nigerian Market
}

\author{
F. J. Faleye*, S. Ogunnubi and O. Olaofe \\ Depertment of Chemistry, University of Ado-Ekiti P.M.B. 5363 Ado-Ekiti Nigeria
}

\begin{abstract}
The chemical and physical analysis of Diamond, Pure Chem, Dangote and Elephant cements in Nigerian market have been carried out by analysis of metal oxides $\left(\mathrm{A}_{2} \mathrm{O}_{3}, \mathrm{SiO}_{2}, \mathrm{CaO}\right.$, etc.), physical characteristics of the samples (setting time, loss on ignition, insoluble residue, specific surface area, etc.) and important factors for predicting effectiveness of the cement samples.The mean value of $\mathrm{CaO}$, $\mathrm{SiO}_{2}, \mathrm{~K}_{2} \mathrm{O}$, and $\mathrm{A}_{2} \mathrm{O}_{3}$ were $61.45 \pm 0.22$ and $5.57 \pm 0.38$ with percentage coefficient of variance as 2.15, 0.92, 53.66 and 6.82, respectively. Dangote had the least $\mathrm{CaO}$ (59.60\%), insoluble residue (4.70) and setting time $(195 \mathrm{sec})$ while pure chem had the highest specific surface area of $412 \mathrm{~m}^{2} / \mathrm{kg}$ with Diamond having the least percentage loss on ignition of 5.50. The mean values for time saturation factor, silica ratio, free lime and alumina ratio were $90.10 \pm 3.022_{2} 2.23 \pm 0.10,169.00 \pm 0.13$ and \pm 0.79 respectively. The coefficient of variation suggests that there were no significant differences between all these factors except free lime. Pure chem has a free lime value of 2.28 which is highly significance compared with others. An empirical equation has been suggested to predict the variation of the compressive strength against time, which agrees very well with the experimental results.
\end{abstract}

Key words: Cement, Diamond, Dangote, Metal oxide, Pure Chem and Quality paramaters .

\section{Introduction}

The use of cementatious materials by mankind in construction is as old as man itself. Cement is very important in the construction works such as buildings, bridges, tunnels etc. Incidences if untimely death or maim amongst construction workers and users of such facilities (houses, bridge etc.) have taken place. One of the factors/explana- tions for the collapse of bridges or tunnels may be due to the poor quality of the cement used in the constructions. Therefore, the quality and chemical paramaters of the cement must be ascertained thereby making it safe and durable in use.

\footnotetext{
* Corresponding author, E- mail: fjfaleye2002@yahoo.com
} 
Literature review revealed that there were no works reported on the quality or chemical analysis of cement available in Nigeria markets. Even the qualities of these cements were not made known to consumers. Hence, there is a great need to investigate the quality or chemical characteristics of the different types of cements in Nigerian market. The only available articles on Nigerian cement were not on its chemical composition but on the effects of exposures of cement dust and powder in benin City (Obuekwe and Okoh, 2005) and the effects of cement production on the elemental composition of soils in the neighbourhood of two cement factories (Asubiojo et al, 1991).

The present study therefore reports the chemical and physical characteristics of Dimond, Pure Chem, Dangote and Elephant cements in Nigerian market by chemical analysis of metal oxides: $\mathrm{CaO}, \mathrm{Fe}_{2} \mathrm{O}_{3}, \mathrm{SiO}_{2}$, $\mathrm{A}_{2} \mathrm{O}_{3}, \mathrm{MgO}, \mathrm{SO}_{3}$ and $\mathrm{K}_{2} \mathrm{O}$. Physical characteristics of the samples : setting time, loss on ignition, insoluble residue, specific surface area and the compressive strength against time have been carried out.

\section{Materials and Methods}

The cement samples were obtained from lock up shops in Ado-Ekiti, Ekiti State, Nigeria. Four different kinds of cements; Diamond, Pure Chem, Dangote and Elephant were used for the study. The experimental work was carried out at WAPCO laboratory Shagamu, Ogun State. All experimental procedures are as described in the laboratory manual available in the portland cement quality control laboratory (Rogers, 2005).

\section{Metals oxides determinaiton}

A mixture of $0.8 \mathrm{~g}$ of stearic acid and $20 \mathrm{~g}$ of each cement sample was placed quantitatively into a grinding dish placed on a milling machine with hammer tightly held on top. The mixture was ground by the machine for about 60secs into a powdery substance, which was added to $1 \mathrm{~g}$ of stearic acid in pellet dish to a level surface. The pellet dish was placed at palletizing position in an X-ray fluorescence machine for analysis (Rogers, 2005).

\section{Free lime determination}

$0.5 \mathrm{~g}$ of each cement samples was placed in an oven-dried beaker and $20 \mathrm{ml}$ mono-ethylene glycol was added and stirred. The beaker with the content was heated on a hot plate for 10 minutes. The mixture was then filtered using a Buckner funnel and washed with $30 \mathrm{ml}$ methylated spirit. The filtrate obtained was titrated with $0.1 \mathrm{~N} \mathrm{HCI}$ to an orange colour end-point using 4 drops of methyl orange indicator the titre value was used to read the \% lime on the chart (Rogers, 2005).

\section{Loss on ignition determination (LOI)}

$1.00 \mathrm{~g}$ of each cement sample was put into a pre weighted dried platinum crucible. The crucible with the content was ignited in the furnace for about 30 minutes at temperature $>900^{\circ} \mathrm{C}$. The crucible was then removed, 
cooled and weighted. The weight of the content was obtained by difference as $\mathrm{W}$. The percentage loss on ignition was calculated by

$$
\% \text { LOI }=(1-W) \times 100
$$

\section{Insoluble residue determination (IR):}

$20.0 \mathrm{~g}$ of each cement sample was poured into 45-micron sieve and placed on Alphine instruement with the coverlid on the sieve. The machine was switched on and the sieving time was set to 5 minutes. The cover was tapped lightly while the sieving was carried out to ensure that all adhered particles fell into the sieve. After 5 minutes, the sieve was removed and the weight of the residue retained, $\mathrm{A}$, was determined. The percentage residue was calculated as follows:

$\%$ Residue $=\frac{\mathrm{A}}{20} \times \frac{100}{1}$

\section{Sepecific surface area determination}

Each sample of the cements was taken using cement tester. The Reynold and Blaine (R and B) apparatus was switched on and allowed to warm up for about 5 minutes. $8.25 \mathrm{~g}$ of each cement samples was put into a tarred dish and was rubbed gently with spatula to disperse any flocs. A 3cm, No. 41 filter paper was put above the perforated disc in the permeability cell. The cement sample taken by the tester was placed quantitatively in the cell and the cell was shaken gently until a level surface was obtained. The plunger was inserted slowly into the cell and the rubber bunger was then inserted. The pointer was set to zero and the tap was on. Using the blowing bulb, the mercury was pumped up to midway. The instrument automatically operated until the pointer stopped at the surface area of the cement (Rogers, 2005).

\section{Setting time determination}

$500 \mathrm{~g}$ of each cement samples was added into $120 \mathrm{ml}$ of water in a mixer dish. The mixer was operated for 1 minute 30 seconds and the mixture was placed on a V-cart to check for consistence by attaching metal rod to the V-cart. The V-cart determines the initial and the final setting time (Rogers, 2005).

\section{Compressive strength determination}

$450 \mathrm{~g}$ of each cement sanple was put into four different containers. $250 \mathrm{ml}$ of water was put into a mixer dish. The mixer dish was placed on the mixer and the cement was added. The mixter was put on for 30 second and 950g of sand was added and the mixer was again operated to ensure uniform mixing. The mould was filled with the mixture and placed inside the jolting machine to jolt for $60 \mathrm{sec}$ ond. After 60 seconds, it was refilled and jolted for another 60 seconds, the mould was leveled with the mixture and covered with plastic and then placed in moist room till next day. Three other test specimens were similarly prepared for 2, 7 and 28 days. The compressive strength was determined for each of the four test specimens (Rogers, 2005). 


\section{Results and Discussion}

Table I presents the chemical analysis of the cement samples. The mean values of $\mathrm{CaO}$, $\mathrm{Fe}_{2} \mathrm{O}_{3}, \mathrm{SiO}_{2}, \mathrm{~A}_{2} \mathrm{O}_{3}, \mathrm{MgO}, \mathrm{SO}_{3}$ and $\mathrm{K}_{2} \mathrm{O}$ were $61.45 \pm 1.33$, $3.31 \pm 0.19$, $20.57 \pm 0.19$, $5.57 \pm 0.38,2.21 \pm 1.05,2.31 \pm 0.14$ and 0.41 \pm 0.22 with percentage coefficient of variance as 2.16, 5.74, 0.92, 6.82, 47.51, 6.06 and 52.66 respectively. Dangote has the highest $\mathrm{A}_{2} \mathrm{O}_{3}$ (6.01\%), $\mathrm{MgO}$ (3.65\%), $\mathrm{SO}_{3}$ (2.46\%), $\mathrm{K}_{2} \mathrm{O}(0.71 \%)$ and the least $\mathrm{CaO}$ (59.6\%) while Pure Chem has the least MgO (1.21\%), $\mathrm{SO}_{3}(2.19 \%)$ and $\mathrm{K}_{2} \mathrm{O}(0.22 \%)$ with Elephant having the highest $\mathrm{CaO}$, (62.6\%). The clinker soluble alkalis such as $\mathrm{K}_{2} \mathrm{O}$ and $\mathrm{Na}_{2} \mathrm{O}$ have an important influence on cement quality and performance. The influence of the soluble alkali content is strongly dependent on the $\mathrm{SO}_{3}$ contents (Rogers, 2005). The Observed $\mathrm{SO}_{3}$ content varies between 2.19 to $2.46 \%$ with a mean of $2.31 \%$ and C.V 6.06 . The percentage of $\mathrm{SO}_{3}$ in all the samples are $<3.5 \%$ which is the upper limit for $\mathrm{SO}_{3}$ content hence there is no risk of failure of heat cure concrete (Rogers, 2005). It has also been revealed that above approximately $2 \%$ of MgO content, the clinker minerals are saturated with $\mathrm{MgO}$ and further increase would contribute fo the quality of clinker liquid, however it does not influence positively the cement strength development (Rogers, 2005).

Tables II and III present the physical parameters and other important factors for the assessment of the cement samples. Dangote has the least insoluble residue (4.7) and setting time (195 seconds) while Pure Chem has the highest specfic surface area of $412 \mathrm{~m} 2 / \mathrm{kg}$ with Diamond having the least percentage loss on ignition of 5.5.

Cement setting time is the time when a part of cement paste offers a certain resistance to penetration by a probe of specified weight and cross section (Rogers, 2005). Hence, Dangote would first show that resistance while Pure Chem would show it last. The mean values for lime saturation factor, silica ratio, free lime and alumina ratio were 90.1 \pm 3.02, $2.23 \pm 0.10,1.69 \pm 0.13$ and $1.43 \pm$

Table I. Chemical oxide composition (\%) of the cement sampal

\begin{tabular}{l|c|c|c|c|c|c|c}
\hline Sampal & $\mathrm{CaO}$ & $\mathrm{Fe}_{2} \mathrm{O}_{3}$ & $\mathrm{SiO}_{2}$ & $\mathrm{Al}_{2} \mathrm{O}_{3}$ & $\mathrm{MgO}$ & $\mathrm{SO}_{3}$ & $\mathrm{~K}_{2} \mathrm{O}$ \\
\hline Diamond & 61.4 & 3.23 & 20.55 & 5.56 & 2.22 & 2.38 & 0.42 \\
Pure Chem & 62.2 & 3.59 & 20.77 & 5.63 & 1.21 & 2.19 & 0.22 \\
Dangote & 59.6 & 3.22 & 20.62 & 6.01 & 3.65 & 2.46 & 0.71 \\
Elephant & 62.6 & 3.20 & 20.34 & 5.09 & 1.74 & 2.19 & 0.29 \\
Mean & 61.45 & 3.31 & 20.57 & 5.57 & 2.21 & 2.31 & 0.41 \\
S.D. & 1.33 & 0.91 & 0.19 & 0.38 & 1.05 & 0.14 & 0.22 \\
CV\% & 2.16 & 5.74 & 0.92 & 6.82 & 47.51 & 6.06 & 53.66 \\
\hline
\end{tabular}


Table II. Physical and chemical properties of the cement samples

\begin{tabular}{l|c|c|c|c}
\hline Sampal & $\begin{array}{c}\text { LOI } \\
(\%)\end{array}$ & $\begin{array}{c}\text { IR } \\
(\%)\end{array}$ & $\begin{array}{c}\text { SSA } \\
\left(\mathrm{m}^{2} / \mathrm{kg}\right)\end{array}$ & $\begin{array}{c}\text { Setting } \\
\text { Time (sec) }\end{array}$ \\
\hline Diamond & 5.5 & 23.9 & 380 & 200 \\
Pure Chem & 6.0 & 34.5 & 412 & 200 \\
Dangote & 8.5 & 4.7 & 358 & 195 \\
Elephant & 8.0 & 33.1 & 392 & 210 \\
Mean & 7.0 & 21.6 & 385 & 201 \\
S.D. & 1.47 & 11.99 & 22.42 & 6.30 \\
CV\% & 21.0 & 55.51 & 5.82 & 3.13 \\
\hline
\end{tabular}

LOI - Loss on ignition (\%), IR - Insoluble residue (\%), SSA - Specific surface area $\left(\mathrm{m}^{2} / \mathrm{kg}\right)$

Table III. Important factors considered for the assessment of the cement samples

\begin{tabular}{l|c|c|c|c}
\hline Sampal & LSF & SR & AR & F/CaO \\
\hline Diamond & 90.2 & 2.34 & 1.72 & 0.84 \\
Pure Chem & 90.1 & 2.25 & 1.57 & 2.58 \\
Dangote & 86.3 & 2.23 & 1.87 & 0.95 \\
Elephant & 93.7 & 2.45 & 1.59 & 1.34 \\
Mean & 90.1 & 2.32 & 1.69 & 1.43 \\
S.D. & 3.02 & 0.10 & 0.13 & 0.79 \\
CV\% & 3.35 & 4.31 & 7.69 & 55.2 \\
\hline
\end{tabular}

LSF - Lime saturation factor, SR - Silica ratio, AR - Alumina ratio, F/CaO - Free lime

0.79 respectively. The coefficient of variation suggests that there were no significant differences between all these factors except free lime. Pure Chem has a free lime value of 2.58 which is highly significance compared with others, which probably accounts for the lower compressive strength of Pure Chem. An increase in clinker free lime reduces the total silicates, which is the main strengthforming phase in hardened cement concrete. Free lime levels above 3\% should certainly be avoided as not only will strengths be reduced but there is a risk of volume instability particularly in high ( $>3 \%$ ) MgO cements (Rogers, 2005).

Fig.1 shows the variation of the compressive strength (CS) with time (days). At low time, the compressive strength increases rapidly as the time increases. After a long time, the compressive strength increases slightly and virtually remains constant. At about 7 days $70 \%$ maximum compressive strength has been nearly achieved. 


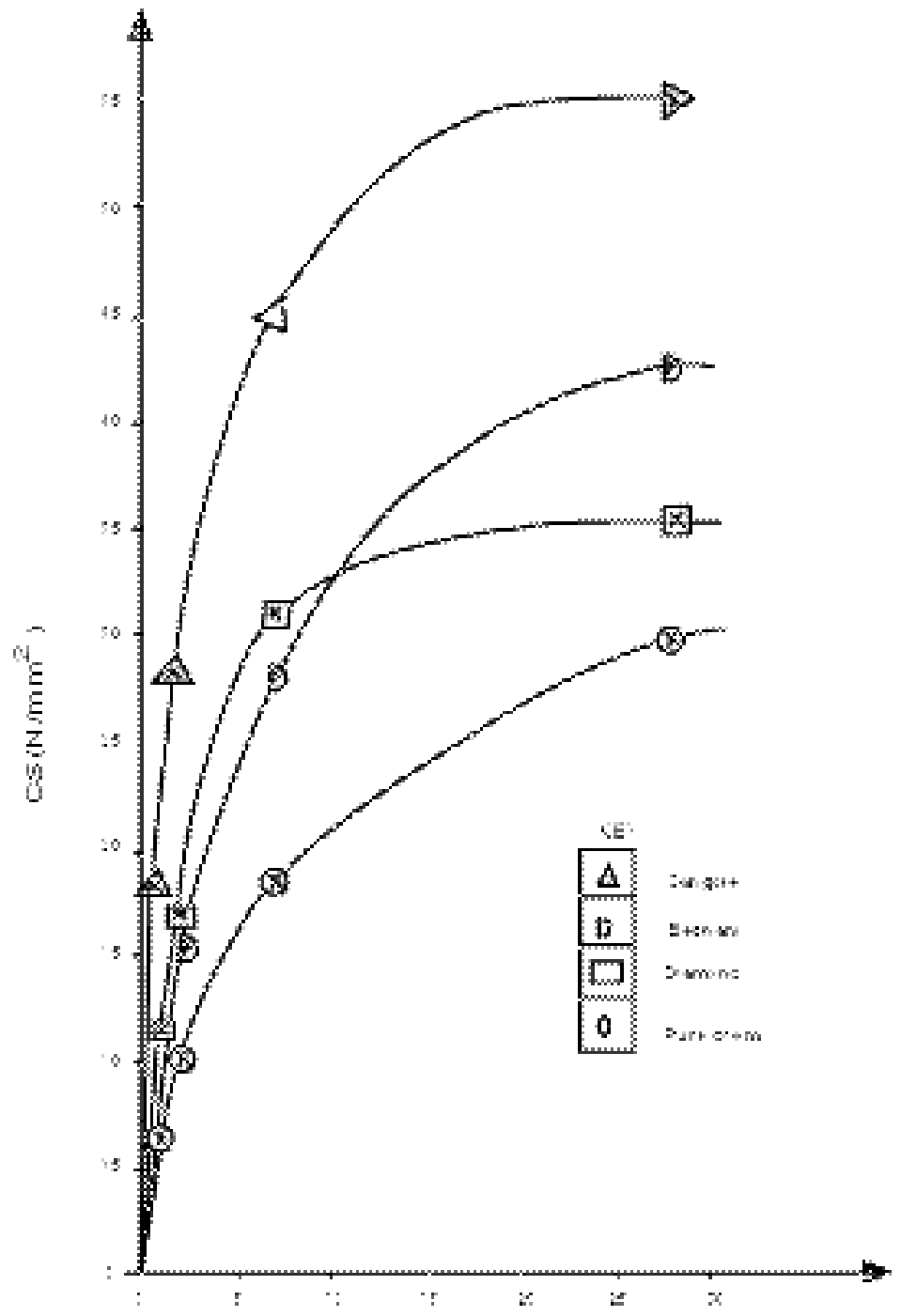

Fig. 1 .The variation of compresstive strength against time

The shape of the curves is virtually similar for all the cement samples. However, Dangote has the highest compressive strength (CS) followed by Elephant and the least is Pure Chem. Explanation for his observation is that Dangote has the lowest specific surface area, and setting time which strongly affect early compressive strength. The variation of the compressive strength against time is correlated with an empirical equation of the form.

$$
\mathrm{CS}=\frac{\mathrm{at}}{1+\mathrm{bt}}
$$


Where $\mathrm{a}$ and $\mathrm{b}$ can be regarded as accelerating compressive strength coefficient and inhibiting compressive strength coefficient. Similar equation has successfully correlated data on absorption, (Gates 1991) leaching, (Olaofe et al, 1999) enzymatic reaction (Yue and Olaote, 1984) and solid catalysed reaction, which have similar shapes of curves.
The linear form is given by

$$
\frac{1}{C S}=\left[\frac{1}{t}\right]+\left[\frac{b}{a}\right]
$$

Fig. 2 shows the linear plots of the inverse of compressive strength against inverse of time. The coefficients $a$ and $b$ for each cement samples were determined using linear regression analysis (Draper and Smith 1966).

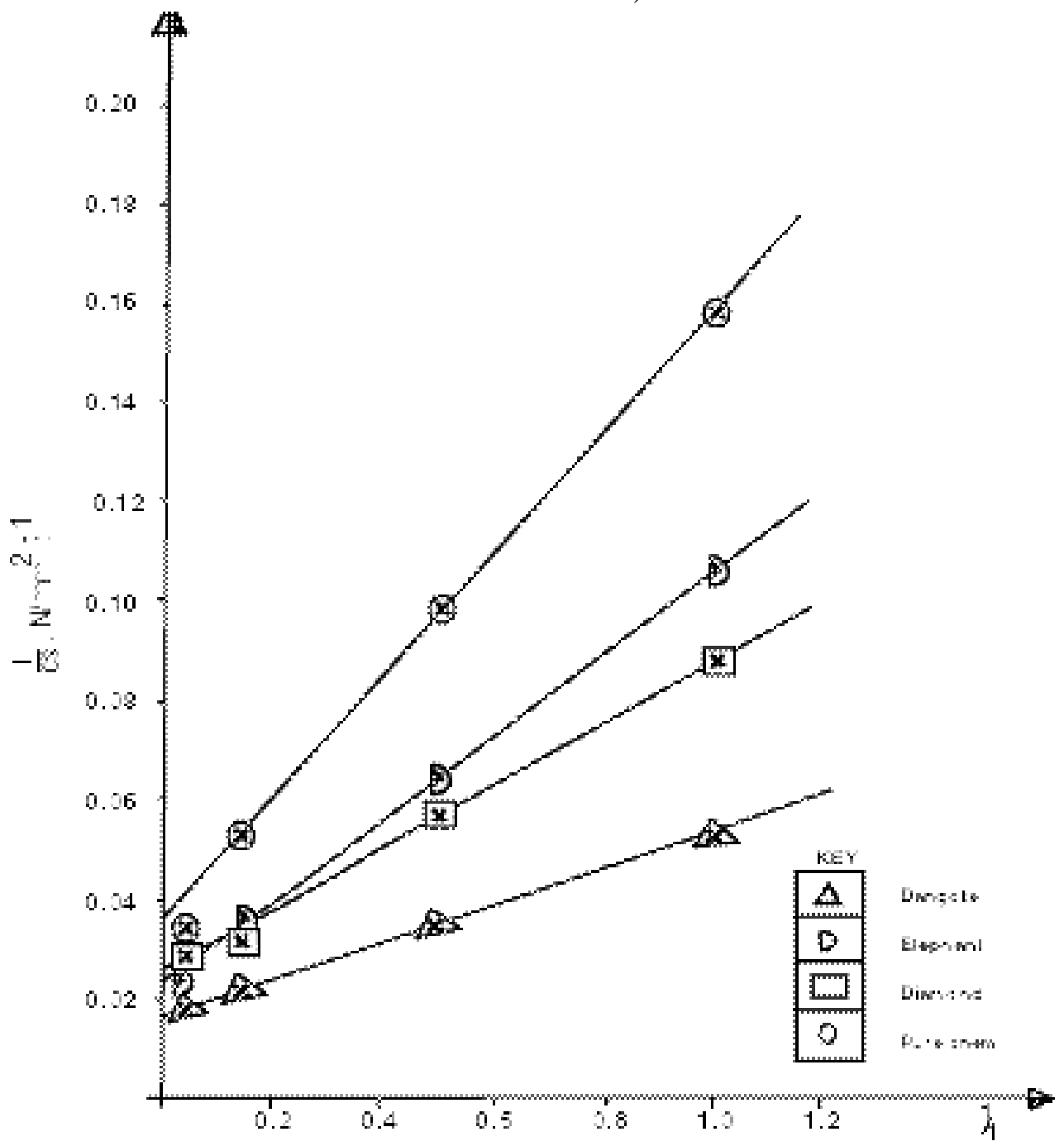

Fig. 2. The plots of inverses of compressive strength against inverse of time 
Dangote has highest compressive strength coefficient of 25.0, while Pure Chem has the least of 8.33. This indicates that Dangote has early compressive strength and rapidly attains the limiting compressive strength. The value of coefficient ' $a$ ' is a good guide or measure for early strength of cement. There is a perfect correlation between the specific surface area and the value of the coefficient. Similarly there is a satisfactory correlation between the setting time and the coefficient ' $a$ '. The higher the coefficient the lower the setting time. Dangote has the least setting time (195) and has the highest coefficient (25.0). It has also been confirmed that specific surface area and setting time have strong effect on the compressive strength (Rogers, 2005).

Table IV summaries the values of coefficients a and b \& other statistical parameters. The equation adequately fitted the experimental data with R-squared over $99 \%$ to each of the regression.
The average deviation was calculated using.

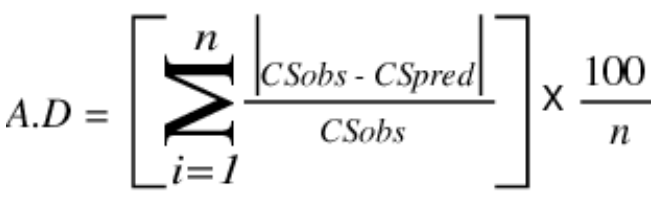

The calculated average deviation varies between $2.23 \%$ and $5.33 \%$ with a mean of $3.45 \%$.

Fig. 3 shows the plot of predicted compressive strength against experimentally determined compressive strength. It is a straight line passing through the origin with a slope 0.98. All these show the suggested empirical equation adequately fitted the experimental data. This equation can be successfully applied to predict the compressive strength of cement at a given time. The coefficient ' $b$ ' varies between 0.30 and 0.43 with an average of 0.36 . This indicates that the depressive coefficient is nearly constant for all cement. The inhibiting factor has no

Table IV. Coefficients and the statistical parameters.

\begin{tabular}{l|c|c|c|c|c}
\hline Sampal & $\mathrm{a}$ & $\begin{array}{c}\mathrm{b} \\
(\%)\end{array}$ & $\begin{array}{c}\mathrm{a} \\
\mathrm{b}\end{array}$ & $\mathrm{R}^{2}$ & \%ADV \\
\hline Diamond & 16.7 & 0.43 & 37.2 & 99.7 & 2.70 \\
Pure Chem & 8.33 & 0.30 & 27.8 & 99.5 & 5.33 \\
Dangote & 25.0 & 0.40 & 62.5 & 99.8 & 2.23 \\
Elephant & 12.5 & 0.30 & 41.7 & 99.6 & 3.90 \\
\hline
\end{tabular}

a- accelerating compressive strength coefficient

b- inhibiting compressive strength coefficient

a/b- attainable maximum compressive strength

$\mathrm{R}^{2}$ - squared of regression coefficient

\%ADV- percentage average deviation 


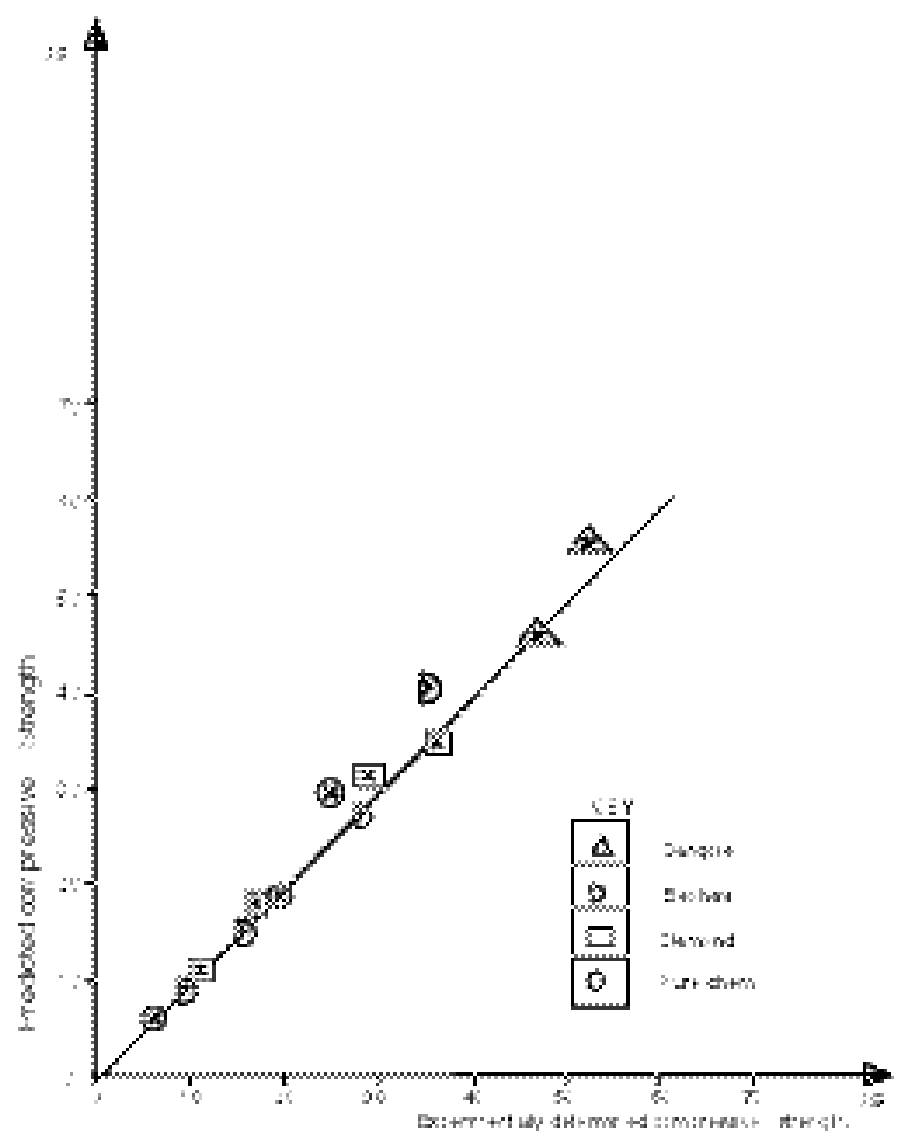

Fig. 3. The predicted compressive strength against the experimentally determined compressive strength

significant effect at low time. That is at low time, the compressive strength is directly proportional to time.

$$
\mathrm{CS}=\text { at } \quad \text { bt }<<1.0
$$

At long time, the attainable compressive strength is independent of time.

$$
\mathrm{CS}=\frac{\mathrm{a}}{\mathrm{b}} \quad \mathrm{bt}>>1.0
$$

$\mathrm{a} / \mathrm{b}$ corresponds to the attainable maximum compressive strength. Dangote has the highest attainable maximum strength of 62.5 while Pure Chem has the least 27.8. At 28 days Dangote and Diamond have developed $88 \%$ and $94 \%$ of the attainable compressive strength, whiles Pure Chem and Elephant have developed nearly $100 \%$ of the attainable compressive strength. In general nearly all the cements have developed over $90 \%$ of the attainable maximum compressive strength suggesting that form work can be removed under decked or concrete work after 28 days. 


\section{Conclusion}

This study has attempted to look at the quality assurance of the cement products. This could help to put the manufacturers at their toes that their products could be assessed by anybody, hence ensuring that the company produces high quality products. The results of this study ciuld help the consumers of the products to make their choices as they will know the best quality cement to purchase. Knowing the setting time of any cement product could help the builders know the right time to remove the formwork uder decken or concrete work. This will definitely reduce the rate of collapsing buildings and deaths of people as a result of collapsed buildings or bridges witnessed yearly.

\section{Acknowledgement}

The authors sincerely appreciate the West African Portland cements Plc for the use of their laboratory.

\section{References}

Asubiojo, O.I. Aina, P.O. Oluwole, A.F. Arshed, W. Akanle, O.A. Spyrou, N.M. (1991). Effect of cement production on the elemental composition of soils in the neighbourhood to two cement factories. Water, Air, and Soil Pollution, 57-58 : 819-828.
Draper, N.R. Smith, H. (1966). Applied regression analysis, John Wiley and sons, New York, pp 20-25.

Gates, B.C (1991). Catalytic chemistry, John Wiley and Sons, New York pp 8-9.

Obuekwe, I.F Okoh, L.I. (2005). Effects of exposures to cement dust and powder on workers in cement distribution retails outlets in Benin City Nigeria. Pak. J. Sci Ind. Res. 48(1) : 23-27.

Olaofe, O. Asaolu, S.S. Olanipekun, E.O. Fatuase, J.B. (1999). Hydrochloric acid leaching of materials from Nigeria soil. Pak. J. Sci.Ind. Res., 42(1): 1-4.

Rogers, A.R. (2005). Principles of quality control. A laboratory manual for West African Portland cement PLC. Sagamu, Nigeria. pp 10-32.

Yue, P.L. Olaofe, O. (1984). Kinetic analysis of the catalytic dehydration of alcohols over zerolites. Chem. Eng. Res. Des 62 :81-92.

Received : January 22, 2008;

Accepted : June 23, 2008. 